\title{
MEDICAL TOURISM POTENTIAL OF CENTRAL AND EASTERN EUROPE: ATTEMPT AT CLASSIFICATION
}

\author{
Adrian Lubowiecki-Vikuk, ${ }^{1}$ Justyna Kurkowiak ${ }^{2}$
}

\begin{abstract}
Medical tourism potential of CEE is currently not clearly identified due to the lack of data concerning the number of medical tourists in respective countries. The aim of the present study is to shed light on potential research topics in the field of medical tourism. A detailed analysis of scientific and consulting literature was used to identify the elements of medical tourism potential. The agglomerative clustering algorithm forms distinct groups of countries that are similar with regard to that potential. Creating the statistical synthetic measures allows one to construct the ranking of countries with respect to their potential regarding medical tourism. Four distinct groups of countries emerge from the cluster analysis. It was found that the countries from the European Union (EU), which are characterized by higher economic indicators, create similar clusters and take the highest positions in the ranking. Surprisingly, the price level is not the top criterion determining the position within the classification. The obtained results fill the gap in the field of medical tourism in CEE and have implications for further research related to medical tourism. This classification could be a useful tool for the various stakeholders interested in the development potential of medical tourism in this part of Europe.
\end{abstract}

JEL Classification Numbers: 015, I11, Z32; DOI: http://dx.doi.org/10.12955/cbup.v5.940

Keywords: Central and Eastern Europe, medical tourism, healthcare, medical tourism potential, Ward's method.

\section{Introduction}

Medical tourism is a characteristic phenomenon of the modern times. Patients take up travel to use health-related services, including services offered as part of tour packages (Connell, 2013; RabPrzybyłowicz, 2016). The scope of the services is wide - they come from the field of preventive care, dental treatment, plastic surgery, aesthetic medicine and dermatology, orthopedics, ophthalmology, gynecology and other (Beladi et al., 2015; Lunt et al., 2014).The concept of medical tourism varies from country to country. Unlike in Western Europe, where the emphasis is put on prevention and maintaining both mental and physical health, in Central and Eastern Europe (CEE), physical health is the main focus. In southern Europe, treatments based on sea water is popular, while in northern Europe spa tourism is based on natural landscapes and treatments using cold lake water (Smith \& Puczkó, 2014). Medical tourism generally takes place at a short distance and has a rather dispersed character, despite being part of an increasingly global medical industry that is linked to the tourism industry (Connell, 2013). There is a need for determination and integration of concepts. Medical tourism is the subject of scientific research by many academics focusing on countries offering medical tourism services: Asian countries, the USA, Mexico, countries of Central and South America. The other medical tourism destinations, CEE countries in particular, are still poorly researched.

The CEE region has a rich tradition in providing a variety of health-related services. Therefore, it is not surprising that this part of Europe is becoming increasingly more prominent on the map of medical tourism destinations (Fetscherin \& Stephano, 2016). Smith et al. (2016) report that the market potential is large and more agencies will specialize in medical tourism in the future. The situation is helped along, among others, by the favorable climate, beautiful and often pristine natural environment, a good position on the map of Europe, and competitive prices for international tourists. On the other hand, health tourism in this region still suffers from a number of weaknesses (cf. Kesar \& Rimac, 2011; Kiss, 2015). The relatively poor infrastructure and the service quality should be improved. The industry needs better education, more training and new skills. Efforts should be made to change the often negative image of the region and build up trust of potential visitors. Another hindrance is poor cooperation between healthcare and tourism, and country-specific regulations. Migration of medical professionals to the EU countries outside of the CEE area is becoming a serious problem, prevention of which requires government support, an innovative approach to eliminating defects and the use of the opportunities and observation of contemporary trends in the market. All these issues need to be addressed in the research on the development of medical tourism in CEE.

The CEE concept has a dual sense: geopolitical and culturo-historical. The opinions on which country should be qualified as belonging to the region vary depending on historical issues, standardization of

\footnotetext{
${ }^{1}$ Poznan University of Physical Education, Poland, alubowiecki@interia.pl

${ }^{2}$ Medical University of Warsaw, Poland, justyna.kurkowiak@wum.edu.pl
} 
geographical names and ideas of representatives of various research centers (UNGEGN, 2016). Each division will spark discussion. Therefore, it is assumed that the CEE region will include the following countries: Albania, Belarus, Bosnia and Herzegovina, Bulgaria, Croatia, Czech Republic, Estonia, Hungary, Kosovo, Latvia, Lithuania, Macedonia, Moldova, Montenegro, Poland, Romania, Serbia, Slovakia, Slovenia and Ukraine.

Since the early1990's, significant socio-demographic changes have been taking place in the CEE region, such as the falling birth-rate, the increasing number of elderly people, the decline in the number of people in households, the changes in the family model and the process of migration (immigration, mainly to larger urban centers of European countries). The region is diverse due to: (i) economic as well as social retardation in comparison with the "old" EU countries, (ii) the varying standard of living in individual countries, (iii) changes in the structure and resources of the healthcare system, and (iv) globalization and its effects (Iordache, Ciochină \& Popa, 2013; Karmowska \& Marciniak, 2015; Romaniuk \& Szromek, 2016). Consumerism encourages the development of tourism, translating into specific benefits for the national economy and changing consumption patterns. At the same time, broadly defined health-related services often become a part of tourist trips or even their main goal.These phenomena significantly shape and differentiate the medical tourism market in the CEE region, which makes it even more difficult to estimate the medical tourism potential. A need has emerged to create favorable conditions for the material and technical, as well as organizational measures in the services sector.

The aim of this paper is to identify the potential of medical tourism destinations in this part of Europe. This would make it possible to prepare medical tourism products that meet tourists' individual needs. The practice of medical tourism depends on successfully informing potential patients about procedure options, treatment facilities, tourism opportunities, travel arrangements, and destination countries (Crooks et al., 2011). The medical tourism potential itself should be treated as a collection of internal, both structural and functional, possibilities of the country enabling the development of medical tourism in its territory.

This study aims to fill the gap in the research on the process of shaping the image of a medical tourism destination, with particular focus on the medical tourism potential. It is also useful in that itis the first step towards a comprehensive analysis of the potential of the medical tourism market in CEE, from which future promotional strategies can be developed. The results will make it possible for medical tourism facilitators / brokers and destination management organizations, as well as for the interested academics, to comprehend the medical tourism phenomenon better.

\section{Methods}

This study concerned with the creation of the classification of CEE countries in terms of medical tourism development potential, for which Ward's method was used along with independent methods of linear order (Ward, 1963, p. 238). The classification is an attempt to determine the potential of individual CEE countries as medical tourism destinations. Nineteen out of 20 CEE countries were taken into account, as Kosovo could not be included in further analyses due to the lack of relevant data. It was assumed that a predisposition to medical tourism development in individual CEE countries is the result of three factors: medical potential and tourism competitiveness of a given country, and the cost of medical services. Ward's algorithms were used to construct the data structure agglomerative clustering. Cluster analysis divides objects (countries) into homogeneous groups based on the information found within the data, describing the objects without establishing a hierarchy between them. Ward's method is regarded as very efficient in capturing the natural structure of the data.

The purpose of this method is to join objects into successively larger clusters, using some measure of similarity defined as the error sum of squares (used in the analysis of variance), defined as ESS = $\sum_{i=1}^{k}\left(X_{i}-\bar{X}\right)^{2}$, where $k$ denotes the number of clusters. The choice of the appropriate variable was determined, apart from the substantive criteria and the accessibility of statistical information (Eurostat, 2015; WHO, 2015), also by the usefulness of the diagnostic variables for Ward's cluster analysis. The analysis requires variables which have sufficient variability and are not too strongly correlated with each other. The threshold value chosen for the coefficient of variation was set to be 0.15 , and for the correlation coefficient to be 0.75 . Because the range of values differs between variables the standardization of data was done so that all attributes were on the same scale. Finally, medical 
potential of the country was determined on the basis of tourists per population, total health expenditure (\$ per capita and \% of GDP), total number of hospitals, number of physicians, nurses and dentists (per 100,000 population), total density of linear accelerator per one million inhabitants and Euro Health Consumer Index (EHCI) 2015 (Björnberg, 2016). Tourism competitiveness of a given country was specified by Travel \& Tourism Competitiveness Index consisting of 14 pillars organized into four subindexes: business environment, safety and security, health and hygiene, human resources and labor market, ICT readiness, prioritization of travel and tourism, international openness, price competitiveness, environmental sustainability, air transport infrastructure, ground and port infrastructure, tourist service infrastructure, natural resources, and cultural resources and business travel (Travel \& Tourism Competitiveness Report, 2015). Due to the assumptions of Ward's method the analysis included the indicators marked in italic. Lack of data on tourism competitiveness of Belarus, Bosnia and Herzegovina and Ukraine was replaced by the average of the corresponding indexes of countries similar in terms of the ratio of GDP per capita and the number of foreign tourists.

The average price level (\$) of selected medical services for medical tourists in various CEE countries was estimated on the basis of a widely available price list (Treatment Abroad, 2015): dental implant, IVF with donor eggs, breast enlargement and gastric bypass.

In the next analysis, the diagnostic variables from Ward's method were aggregated to determine the synthetic measure in order to create the ranking of countries with respect to their potential regarding medical tourism. There exist a number of methods for creating a synthetic variable. Three different methods were used to compare the resulting rankings and to check if the choice of a particular method affected the ranking order.

First, we followed the methodology proposed by Hellwig (1968).For the given $m$ objects described by $n$ standardized variables $Z_{i j}$, where $i=1,2, \ldots, m, j=1,2, \ldots, n$, the model patterned object $z_{0 j}$ was chosen which is described as follows:

$$
z_{0 j}=\left\{\begin{array}{l}
\max _{i}\left\{z_{i j}\right\}, \quad \text { if variable is stimulant } \\
\min _{i}\left\{z_{i j}\right\}, \quad \text { if variable is destimulant }
\end{array}\right.
$$

Then, for each of $m$ objects the distance from the patterned object model was computed According to Euclidean measure: $d_{i 0}=\sqrt{\sum_{j=1}^{m}\left(z_{i j}-z_{o j}\right)^{2}}$. Those distances were used to calculate the synthetic measure which was next used to construct a linear order:

$$
h_{i}=1-\frac{d_{i 0}}{\overline{d_{0}}+2 s}, \quad i=1,2, \ldots, m
$$

where $\overline{d_{0}}$ and $s$ denote, respectively, the average and standard deviation for the calculated distances, i.e. $\overline{d_{0}}=\frac{1}{n} \sum_{i=1}^{n} d_{i 0}, s=\sqrt{\frac{\sum_{i=1}^{n}\left(d_{i 0}-\overline{d_{0}}\right)^{2}}{n}}$.

The next two methods are not model methods: the average ranks method (Brazdil \& Soares, 2000) and the zero unitarization method (Kukuła \& Bogocz, 2014). The average ranks method for standardized variables calculates the average rank for each object according to the formula:

$$
r_{i}=\frac{\sum_{j=1}^{n} r_{i j}}{n} i=1,2, \ldots, m
$$

Stimulant variables that are ranked $r_{i j}$ from the highest to the lowest, and destimulant variables from the lowest to the highest. If two or more scores have the same value then they are 'tied', i.e. first, each tied score is given a rank it would have, if it was different from the other scores. Then, the ranks for the tied scores are added and divided by the number of tied scores. This way each tie gets the same average rank.

In the third method, the selected diagnostic variables were subjected to the normalization process by using the zero unitarization method. If the variables are stimulants the normalization is performed using the following formula: 


$$
z_{i j}=\frac{x_{i j}-\min _{i}\left\{x_{i j}\right\}}{\max _{i}\left\{x_{i j}\right\}-\min _{i}\left\{x_{i j}\right\}} .
$$

If the variables are destimulants, the appropriate formula is as follows:

$$
z_{i j}=\frac{\max _{i}\left\{x_{i j}\right\}-x_{i j}}{\max _{i}\left\{x_{i j}\right\}-\min _{i}\left\{x_{i j}\right\}} .
$$

For each object the synthetic variable $u_{i}$ is defined as the average of normalized diagnostic variables: $u_{i}=\frac{\sum_{j=1}^{n} z_{i j}}{n}$.

Spearman's rank correlation coefficient, which is a measure of the strength of the relationship between data, was calculated to check if the selected measures brought similar classification results. All statistical analyses were and conducted using data analysis software system StatSoft, Inc. (2014). STATISTICA, version 12. www.statsoft.com. The significance level was set as $p \leq 0.05$.

\section{Results}

In view of the factors influencing the development of medical tourism in CEE, the countries were grouped, which resulted in a dendrogram illustrating the hierarchical structure of the countries (Figure $1)$.

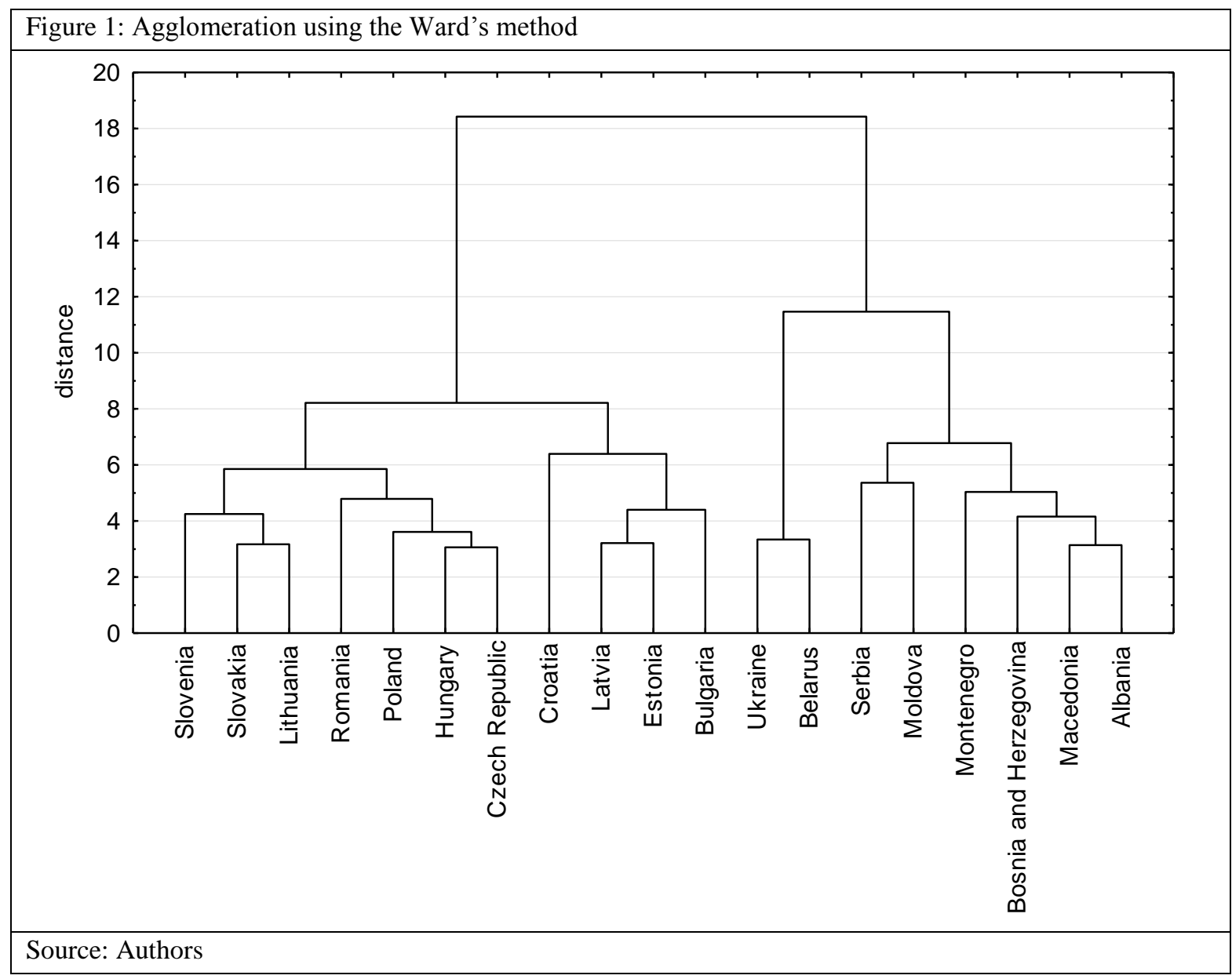

The adoption of binding distance of 7 allowed us to distinguish four clusters (Table 1). The first group consists of Belarus and Ukraine. The group is characterized by a medium number of tourists, lower expenditure on health per capita, and at the same time a higher than average number of hospitals, physicians, nurses and dentists. Lower economic indicators are also noticeable, the EHCI at 0 and low prices of selected medical services in the CEE countries. The second group (Czech Republic, Hungary, 
Lithuania, Poland, Romania, Slovakia, Slovenia) and the third one (Bulgaria, Croatia, Estonia, Latvia), are characterized by higher than average economic indicators, expenditure on health and EHCI level. The number of tourists constitutes a differentiating factor. In the second group it is at an average level, while in the third group it is higher than average. Both groups are made up of countries belonging to the EU. Albania, Bosnia and Herzegovina, Macedonia, Moldova, Montenegro and Serbia make up the last group which is characterized by a lower than average number of tourists, lower expenditure and economic indicators, lower EHCI level and the highest prices of selected medical services of all CEE countries.

\begin{tabular}{|c|c|c|c|c|c|}
\hline \multirow[b]{3}{*}{ Tourists per population } & \multirow{2}{*}{ Total } & \multicolumn{4}{|c|}{ cluster centroids } \\
\hline & & 1 & 2 & 3 & 4 \\
\hline & $0.8 \pm 0.8$ & $0.3 \pm 0.4$ & $0.8 \pm 0.3$ & $1.4 \pm 1.1$ & $0.6 \pm 0.8$ \\
\hline $\begin{array}{l}\text { Total health expenditure } \\
\text { per capita }\end{array}$ & $1169 \pm 559.4$ & $713.4 \pm 150$ & $1610.6 \pm 595.2$ & $1248.2 \pm 174.3$ & $752.8 \pm 331.1$ \\
\hline $\begin{array}{l}\text { Total health expenditure } \\
\text { as \% of GDP }\end{array}$ & $7.4 \pm 1.8$ & $6.4 \pm 1.3$ & $7.1 \pm 1.7$ & $7 \pm 0.8$ & $8.3 \pm 2.3$ \\
\hline $\begin{array}{l}\text { Hospitals per } 100.000 \\
\text { population }\end{array}$ & $2.7 \pm 1.6$ & $6.2 \pm 1.1$ & $2.3 \pm 0.6$ & $3.4 \pm 1.5$ & $1.5 \pm 0.6$ \\
\hline $\begin{array}{l}\text { Physicians per } 100.000 \\
\text { population }\end{array}$ & $285.4 \pm 78.2$ & $364.2 \pm 21.4$ & $300.1 \pm 66.7$ & $327.5 \pm 43.1$ & $213.9 \pm 71.8$ \\
\hline $\begin{array}{l}\text { Nurses per } 100.000 \\
\text { population }\end{array}$ & $612.2 \pm 202.8$ & $901.3 \pm 215.8$ & $687.1 \pm 120.8$ & $423.9 \pm 254.2$ & $554.1 \pm 93.3$ \\
\hline $\begin{array}{l}\text { Dentists per } 100.000 \\
\text { population }\end{array}$ & $54.4 \pm 23.2$ & $60.3 \pm 8.8$ & $59.1 \pm 15.6$ & $80.4 \pm 10.5$ & $29.5 \pm 15$ \\
\hline $\begin{array}{l}\text { Linear accelerators per } \\
\text { million population }\end{array}$ & $2.1 \pm 1.5$ & $0.5 \pm 0.1$ & $2.8 \pm 1.6$ & $2.4 \pm 1.5$ & $1.4 \pm 1.1$ \\
\hline EHCI 2015 & $483.2 \pm 232.2$ & $0 \pm 0$ & $588.9 \pm 98.8$ & $614.3 \pm 56.5$ & $433.5 \pm 234.1$ \\
\hline Dental implant & $807.4 \pm 233$ & $547.5 \pm 31.8$ & $1017.1 \pm 135.4$ & $750 \pm 94.3$ & $687.5 \pm 243.8$ \\
\hline IVF with donor eggs & $5055 \pm 900.3$ & $4580 \pm 1315.2$ & $4395.7 \pm 350.3$ & $5972.5 \pm 730.5$ & $5370.8 \pm 782.7$ \\
\hline Breast enlargement & $3228.7 \pm 940.3$ & $1212.5 \pm 17.7$ & $3342.1 \pm 141.6$ & $3633.8 \pm 465.5$ & $3498.3 \pm 1080$ \\
\hline Gastric bypass & $8123.7 \pm 3521.7$ & $6462.5 \pm 1361.2$ & $7419.3 \pm 1640.1$ & $4715 \pm 3021.7$ & $11771.7 \pm 2917$ \\
\hline International openness & $3.3 \pm 0.9$ & $2.2 \pm 0.3$ & $4 \pm 0.2$ & $3.9 \pm 0.2$ & $2.3 \pm 0.2$ \\
\hline $\begin{array}{l}\text { Air transport } \\
\text { infrastructure }\end{array}$ & $2.5 \pm 0.4$ & $2 \pm 0.2$ & $2.5 \pm 0.4$ & $2.9 \pm 0.3$ & $2.3 \pm 0.4$ \\
\hline $\begin{array}{l}\text { Tourist service } \\
\text { infrastructure }\end{array}$ & $4.9 \pm 0.9$ & $3.6 \pm 0.5$ & $5 \pm 0.5$ & $5.8 \pm 0.5$ & $4.5 \pm 0.9$ \\
\hline Natural resources & $2.6 \pm 0.7$ & $1.9 \pm 0.2$ & $3 \pm 0.5$ & $3.1 \pm 0.6$ & $2.1 \pm 0.4$ \\
\hline $\begin{array}{l}\text { Cultural resources and } \\
\text { business travel }\end{array}$ & $1.6 \pm 0.5$ & $1.1 \pm 0.0$ & $2 \pm 0.5$ & $1.9 \pm 0.6$ & $1.3 \pm 0.2$ \\
\hline
\end{tabular}

The use of tools of the multidimensional comparative analysis allowed us to create a ranking of CEE countries as shown in Table 2.

The rankings of CEE countries received large consistency of the results confirmed by the high value of the Spearman's rank correlation coefficient (about 0.93 for each pair). In the general classification, the leading positions are occupied by the EU countries, the last by Moldova and Albania. 


\begin{tabular}{|c|c|c|c|}
\hline \multirow[b]{2}{*}{ Country } & \multicolumn{3}{|c|}{ The position of the ranking } \\
\hline & $\begin{array}{c}\text { Hellwig's } \\
\text { synthetic } \\
\text { measure }\end{array}$ & $\begin{array}{l}\text { Average } \\
\text { ranks } \\
\text { measure }\end{array}$ & $\begin{array}{c}\text { Zero } \\
\text { unitarization } \\
\text { measure }\end{array}$ \\
\hline Albania & 19 & 19 & 19 \\
\hline $\begin{array}{l}\text { Bosnia and } \\
\text { Herzegovina }\end{array}$ & 13 & 17 & 13 \\
\hline Belarus & 15 & 16 & 15 \\
\hline Bulgaria & 4 & 7 & 8 \\
\hline Croatia & 10 & 5 & 3 \\
\hline Czech Republic & 1 & 1 & 2 \\
\hline Estonia & 3 & 4 & 4 \\
\hline Hungary & 9 & 8 & 10 \\
\hline Latvia & 6 & 9 & 5 \\
\hline Lithuania & 7 & 6 & 6 \\
\hline Macedonia & 16 & 15 & 16 \\
\hline Montenegro & 12 & 11 & 11 \\
\hline Poland & 8 & 10 & 9 \\
\hline Moldova & 18 & 18 & 18 \\
\hline Romania & 14 & 13 & 14 \\
\hline Serbia & 17 & 14 & 17 \\
\hline Slovakia & 5 & 3 & 7 \\
\hline Slovenia & 2 & 2 & 1 \\
\hline Ukraine & 11 & 12 & 12 \\
\hline
\end{tabular}

\section{Discussion}

Medical tourism is an example of not only the possibility of economic revival in the CEE countries, but also specific consequences of various factors affecting decisions about medical treatment abroad (Directive 2011/24/EU, 2011; Fetscherin \& Stephano, 2016).This is due to the medical tourism potential. According to our own research, the following countries occupied top places in this regard: Czech Republic, Slovenia, Estonia, Slovakia, Croatia, Bulgaria, Lithuania, Latvia, Hungary and Poland.

Marinau et al. (2009, p. 282) emphasized that countries such as Hungary, Slovenia, Czech Republic, Slovakia and Poland, which made considerable investment efforts to modernize and develop their resorts, are currently major competitors for many countries of Western Europe with tradition of medical tourism. An increase in exports of health services in the countries such as Estonia, Latvia, Lithuania and Croatia has been observed (Langvinienè, 2014, p. 312). Bulgaria, which also continually improves its offer of health tourism, is becoming a major rival of Romania (Marinau et al., 2009, p. 283).

Medical tourism development is possible thanks to the support from EU funds, and drawing particular attention of the representatives of private companies to the quality of medical services, while maintaining an optimal level of their prices. Furthermore, in most of these countries, the health systems are also run properly (Romaniuk \& Szromek, 2016, p. 95). Safety as well as attractiveness of 
tourist destinations constitute an additional advantage of the leaders in the CEE countries ranking. The Czech Republic, Slovenia, Hungary and Poland are currently a group of safe destinations in this part of Europe (2015 Global Peace Index, 2015).

CEE countries outside the EU (except for Romania in the 13th-14th place) occupy significantly lower places (11-19) in the overall classification in terms of medical tourism potential. The lack of subsidies is a major cause of this situation. The case of Montenegro proves how crucial subsidies are. The country received government support, thanks to which (as Smith et al. suggest) health tourism has increased by $20 \%$ in the past five years, mainly because of the medical tourism industry (Smith et al., 2016).

The price of medical tourism products and services, which substantially affects the participation in medical travel (Lubowiecki-Vikuk \& Rab-Przybyłowicz, 2015, p. 85), is believed to be an allocative effect of medical tourism market function. In this respect, the lowest prices of medical services in Belarus and Ukraine or the highest in CEE in Serbia, Moldova, Macedonia, and Montenegro (Treatment Abroad, 2015), did not result in high places in the ranking of medical tourism potential in the studied region. Moreover, a low position in this classification may be associated with different health care systems of CEE countries. According to Romaniuk and Szromek (2016), Albania, Belarus, Moldova, and Ukraine are among the countries whose health systems are the weakest and with least improvements in recent years. Given the above, it is the quality, not the price of medical services that is the priority for medical tourism development. Poland occupies 8-10th place in the overall classification of the CEE countries. It should be noted that Poland was the only country in the CEE region included in the Medical Tourism Index (Fetscherin \& Stephano, 2016, p. 541).

The authors assumed that medical tourism potential is a collection of internal, both structural and functional possibilities of the country, enabling the development of medical tourism in its territory. Scientists do not have access to many variables because the appropriate data are not available. The created clusters give a general idea of the CEE region, however, it deserves more attention in regard to medical tourism. The variables used speak of the current state of things rather than future.

Given those limitations, the authors are aware of the fact that their initiative should be continued and would constitute a basis for further research in this area, taking into account an increasing number of studies on medical tourism.

\section{Conclusions}

The CEE countries, especially those belonging to the EU, in many respects, such as health, economy, tourism, favorable prices, together broadly defined as the medical tourism potential, are becoming more and more attractive for citizens of countries with developed economies. The countries characterized by higher economic indicators create similar clusters and take the highest position in the ranking (e.g. the Czech Republic, Slovenia, Estonia, and Slovakia).

In the future, identification of the CEE medical tourism potential will help to determine the brand of a given destination. It should be noted, however, that the ongoing economic, political and religious instability and conflicts in the region can damage its image and limit the potential.

\section{Acknowledgement}

Thanks to Dominika Mucha the final manuscript is infinitely better than anything that we could have produced without her support.

\section{References}

2015 Global Peace Index: Measuring peace, its causes and its economics value. (2015). Report 34. Institute for Economics and Peace. Retrieved from http://economicsandpeace.org/wp-content/uploads/2015/06/Global-Peace-Index-Report2015_0.pdf

Beladi, H., Chao, Ch.-Ch., Ee, M. S., \& Hollas, D. (2015). Medical tourism and health worker migration in developing countries. Economic Modelling, 46, 391-396. doi:10.1016/j.econmod.2014.12.045

Björnberg, A. (2016). Euro Health Consumer Index 2015. Report. Health Consumer Powerhouse Ltd., Täby. Retrieved from http://www.healthpowerhouse.com/files/EHCI_2015/EHCI_2015_report.pdf

Brazdil, P.B., \& Soares, C. (2000). A comparison of ranking methods for classification algorithm selection. In: de Mántaras, R. \& Plaza, E. (Eds.), Machine Learning: Proceedings of the $11^{\text {th }}$ European Conference on Machine Learning ECML 2000. Springer, Berlin, pp. 63-74. 
Connell, J. (2013). Contemporary medical tourism: Conceptualisation, culture and commodification. Tourism Management, 34, 1-13. doi:10.1016/j.tourman.2012.05.009

Crooks, V.A., Turner, L., Snyder, J., Johnston, R., \& Kingsbury, P. (2011). Promoting medical tourism to India: Messages, images, and the marketing of international patient travel. Social Science \& Medicine, 72, 726-732.

doi:10.1016/j.socscimed.2010.12.022

Directive 2011/24/EU of the European Parliament and of the Council of 9 March 2011 on the application of patients' rights in cross-border healthcare. Official Journal of the European Union, 50(88), 45.

Eurostat. Statistics Explained (2015). Retrieved from http://ec.europa.eu/eurostat/statistics-

explained/index.php/File:Hospital_beds,_2001,_2006_and_2011_(per_100_000_inhabitants)_YB15_bis.png

Fetscherin, M., \& Stephano, R. M. (2016). The medical tourism index: Scale development and validation. Tourism Management, 52, 539-556. doi:10.1016/j.tourman.2015.08.010

Hellwig, Z. (1968). On the optimal choice of predictors. Study VI. In: Gostkowski, Z. (Ed.), Toward a system of quantitative indicators of components of human resources development. UNESCO, Paris, pp. 1-23.

Iordache, C., Ciochină, I., \& Popa, R. (2013). Medical tourism - between the content and socio-economic development goals. Development strategies. Romanian Journal of Marketing, 1, 31-42.

Karmowska, G., \& Marciniak, M. (2015). Spatial diversification of living standards in the former communist countries of Central and Eastern Europe and the Balkans. Comparative Economic Research,18(4), 123-138. doi:10.1515/cer-2015-0032

Kesar, O., \& Rimac, K. (2011). Medical tourism development in Croatia. Zagreb International Review of Economics \& Business, 14(2), 107-134.

Kiss, K. (2015). The challenges of developing health tourism in the Balkans. Tourism, 63, 97-110.

Kukuła, K., \& Bogocz, D. (2014). Zero unitarization method and its application in ranking research in agriculture. Economic and Regional Studies, 7(3), 5-13.

Langviniene, N. (2014). Changing patterns in the health tourism services sector in Lithuania. Procedia - Social and Behavioral Sciences, 156, 310-316. doi:10.1016/j.sbspro.2014.11.194

Lubowiecki-Vikuk, A., \& Rab-Przybyłowicz, J. (2015). Wybrane aspekty funkcjonowania rynku turystyki medycznej w Polsce. Folia Turistica, 34, 85-107.

Lunt, N., Smith, R.D., Mannion, R., Green, S.T., Exworthy, M., Hanefeld, J., \& et al. (2014). Implications for the NHS of inward and outward medical tourism: A policy and economic analysis using literature review and mixed-methods approaches. Health Services and Delivery Research, 2(2), 1-234. doi:10.3310/hsdr02020

Marinau, C., Csosz, I., Martin, S.C., \& Ciolac, R. (2009). European experience in the field of health tourism, overview of the countries of Western Europe, Central and Eastern Europe. Management Agricol, 11(4), 279-288.

Rab-Przybyłowicz, J. (2016). Medical tourism: Theoretical considerations. Studia Periegetica, 2, 13-31.

Romaniuk P., \& Szromek, A.R. (2016). The evolution of the health system outcomes in Central and Eastern Europe and their association with social, economic and political factors: An analysis of 25 years of transition. BMC Health Services Research, 16, 95. doi:10.1186/s12913-016-1344-3

Smith, M., \& Puczkó, L. (2014).Health, tourism and hospitality: Wellness, spas and medical travel. 2nd ed. Routledge, London.

Smith, M., Puczkó, L., Michalkó, G., Kiss, K., \& Sziva, I. (2016). Balkan wellbeing and health tourism study. Final Report. MetropolitanUniversity, Budapest. Retrieved from http://infota.org/wpcontent/uploads/2016/03/BalkanWellbeingFINALREPORT.pdf

Travel \& Tourism Competitiveness Report. (2015). World Economic Forum, New York. Retrieved from http://reports.weforum.org/travel-and-tourism-competitiveness-report-2015/index-results-the-travel-tourism-competitivenessindex-ranking-2015/

Treatment Abroad. (2015). Compare the cost of treatment abroad. Retrieved from http://www.treatmentabroad.com/costs

UNGEGN. (2016).East Central and South-East Europe Division. Retrieved from http://ecseed.zrc-sazu.si

Ward, J.H. (1963). Hierarchical Grouping to Optimize an Objective Function. Journal of the American Statistical Association, 58(301), 236-244.

WHO. (2015). Regional office for Europe. Retrieved fromhttp://www.euro.who.int/en/countries 